\title{
Comparison of time-restricted feeding and Islamic fasting: a scoping review
}

Suriani Ismail, ${ }^{1}$ Rosliza Abdul Manaf ${ }^{1}$ and Aidalina Mahmud ${ }^{1}$

${ }^{1}$ Department of Community Health, Faculty of Medicine and Health Sciences, University Putra Malaysia, Selangor, Malaysia (Correspondence to: Suriani Ismail: si_suriani@upm.edu.my).

\begin{abstract}
Background: Research on the health benefits of fasting is growing; this includes time-restricted feeding and Islamic fasting.

Aims: This article aims to review and highlight the similarities and differences between time-restricted feeding and Islamic fasting during Ramadan.

Methods: A scoping review was undertaken to identify relevant articles that answered the research question: what are the similarities and differences in characteristics of time-restricted feeding and Islamic fasting? MEDLINE/PubMed was searched using the terms: time-restricted feeding, and weight. Inclusion criteria were: original research and review articles; written in English; and published between the years 2000 and 2017.

Results: A total of 25 articles that answered the research question were included in the review: 15 original research papers and 10 reviews. The findings suggest that Ramadan fasting is a form of time-restricted feeding in the contemporary context because of the period when eating is not allowed. The fasting duration reported in time-restricted feeding ranged from 4 to 24 hours, which is longer than that of Islamic fasting which is between 8 and 20 hours. Both time-restricted feeding and Islamic fasting have been found to have positive health effects, including weight reduction.
\end{abstract}

Conclusion: Time-restricted feeding and Islamic fasting have many similar characteristics and reported positive health effects.

Keywords: Fasting, time-restricted feeding, eating, Islam

Citation: Ismail S; Abdul Manaf R; Mahmud A. Comparison of time-restricted feeding and Islamic fasting: a scoping review. East Mediterr Health J. 2019;25(4):239-245. https://doi.org/10.26719/emhj.19.011

Received: 24/08/17; accepted: 24/12/17

Copyright @ World Health Organization (WHO) 2019. Some rights reserved. This work is available under the CC BY-NC-SA 3.o IGO license (https:// creativecommons.org/licenses/by-nc-sa/3.o/igo).

\section{Introduction}

Fasting is a spiritual practice in several faiths and has been researched as a treatment for some medical conditions such as hypertension and cancer $(1,2)$. In addition, research on fasting for other health reasons is increasing, such as its use as an effective and reasonably safe method to lose weight (3). Most of these were experimental studies carried out in laboratories using animals. However, several studies on humans have been conducted to monitor food intake, for example monitoring of predetermined allowable calories or time-restricted feeding.

The literal definition of fasting is voluntarily refraining from consuming food for a certain length of time. In the current literature on fasting, the definition varies, and includes consuming only water (1) and sometimes juices (also known as modified fasting), consuming $25 \%$ of baseline energy needs (4) and consuming less than 500 calories within 24 hours (also known as a very-lowcalorie diet).

Other terminology is used in research on fasting such as intermittent fasting and nocturnal eating. Intermittent fasting means a cycle of a period of fasting and one of nonfasting - the interval between these two periods ranges from a few hours to 24 hours or more (5). Intermittent fasting includes at least two variants - time-restricted feeding and intermittent energy restriction. Timerestricted feeding means allowing food consumption during a much smaller period of time than people are normally used to (6), while intermittent energy restriction is an eating pattern of regular daily periods of restricted energy intake followed by periods of unrestricted energy intake (6). Among the most commonly used fasting patterns are alternate-day fasting, two-day-a-week fasting (5:2) and duration fasting ranging from 5 to 40 days. However, comparative research on the effects restricted food intake and fasting on weight loss is still sparse in clinical settings and at the community level.

None of the contemporary definitions of fasting is the same as the definition of Islamic fasting, either the compulsory month-long fasting during the month of Ramadan (Ramadan fasting) or voluntary fasting (Sunnah fasting). In Islamic fasting, Muslims refrain from consuming both food and water from sunrise to sunset. Therefore, the duration of daily fasting varies according to the time from sunrise to sunset in a particular location. In countries located near the equator, the duration of fasting is about 14 hours and the allowable feeding time is about 10 hours. However, in countries further away from the equator, the duration of fasting varies according 
to the season - longer in summer (more than 20 hours) and shorter in winter (less than 8 hours) (7).

The number of days for compulsory fasting during Ramadan is 28 or 29 days (one lunar month), while the number of days for voluntary fasting varies. The more commonly practised voluntary fasting includes twodays-a-week fasting (5:2) on Mondays and Thursdays, 3-days-a-month fasting and alternate-day fasting. Other days on which Muslims are encouraged to perform voluntary fasting are 6 days in the month of syawal and the day of arafah (associated with the Hajj pilgrimage).

Although Islamic fasting has some of the same elements as time-restricted fasting, there is no restriction on energy or calorie intake and the duration of fasting is compulsory for one lunar month a year and voluntary for several days a year.

This review attempts to highlight the similarities and differences between time-restricted feeding and Islamic fasting and their effects on weight and health.

No ethical clearance was sought for this study as it was a review of the literature.

\section{Methods}

A scoping review methodology was chosen as a framework to map the relevant literature. The framework consists of the following main stages: identifying the research question; identifying relevant studies using a systematic literature search based on the formulated research question; selecting the studies; tabulating the findings; and collating, scrutinizing, summarizing and reporting the results $(8,9)$.

This review was divided into two parts. The first part was guided by the research question "What are the characteristics and findings of research on current timerestricted feeding which is not Ramadan fasting?" The second part was guided by the question "What are the findings of published systematic reviews of Ramadan fasting?" The literature search was conducted on 16 May 2017. The electronic databases, MEDLINE/PubMed were searched using the Boolean operator "AND". The search terms used were: "time-restricted feeding" and "weight" (one of the most common studied outcome variable) (10). Inclusion criteria for the articles were: original research and review article; written in the English; and published between the years 2000 and 2017. We also searched on Google and hand-searched for other documents.

The selection of articles was done in three stages. The first stage was reviewing the titles of studies. After exclusion of duplicates and non-relevant titles, the second stage was reviewing the titles and the abstracts. After further exclusions, the final stage was reviewing the full texts of the articles retained. The data recorded for the original research articles were: author and year of publication, title of article, subject of the intervention (humans or animal), feeding period and duration of timerestricted feeding.

For the question of part one, the search yielded 43 articles and nine more articles from other sources. After duplications were removed, 45 articles were screened in more depth. After this, 23 articles were removed because they did not study time-restricted feeding or the effects of interest. Of the 22 articles remaining, 15 were original research (6,11-24) and six were reviews (3,5,10,25-27). For the question of part two, three systematic reviews were selected (28-30). A summary of the selected research articles is given in Table 1 and includes the feeding time, duration of time-restricted feeding and type of diet.

\section{Results and discussions}

\section{Feeding time and diurnal variation}

Among the six human research studies on time-restricted feeding, the shortest feeding time was 4 hours (11-14). The others were 8 and 12 hours $(15,16)$. The 4 -hour feeding times were all in the evening (the 4 hours started between 16:00 and 18:00 and end between 20:00 and 24:00) (11-14). The 8-hour feeding time was from 13:00 to 21:00, and the 13-hour feeding time was from 06:00 to 19:00 $(15,16)$. The feeding times in the animal experiments were generally longer, between 8 and 12 hours; in five experiments the feeding time was 8 hours (17-21), in one experiment it was 9 hours $(22)$, in three it was 12 hours $(21,23,24)$ and in one experiment the hours varied (6).

In contrast, the period for Islamic fasting in general is between 8 and 20 hours. The feeding time varies according to the location and time of year. The shortest feeding time is about 4 hours in summer while it is 16 hours in winter. In most countries, the feeding time is about 10 hours. Thus, the Islamic fasting is never for 24 hours, not even for Muslims in the North and South poles where there are 24 hours of daylight in summer and 24 hours of night in winter, because Muslims in these parts of the world can follow the timing for fasting of the nearest country that has a shorter day or night, and this is generally still between 8 and 20 hours of fasting (7).

The other aspect that has been studied in timerestricted feeding is the time of feeding either in the dark cycle/inactive phase or vice versa, in other words, the circadian variation in feeding pattern. In three animal studies, feeding during the dark phase was studied $(18,21,22)$. Most of the feeding times in time-restricted feeding research were during day time and lasted up to midnight for both animals and humans. There is no human study on circadian variation however it is similar to the feeding pattern in Islamic fasting. Food and drink are consumed after sunset and can be consumed until sunrise when total abstinence from food and water starts; this is known as dark phase in time-restricted feeding experiments.

A review of night-time eating reported that eating at night is harmful as it makes one susceptible to obesity (31). However, a more recent review reported that for some types of food such as protein, pre sleep nutrient intake does not cause weight gain and is even linked to potential benefits (25). Furthermore, another study suggested that nocturnal timing can prevent obesity and rectify the harmful effects of a high-fat diet in mice (26). 


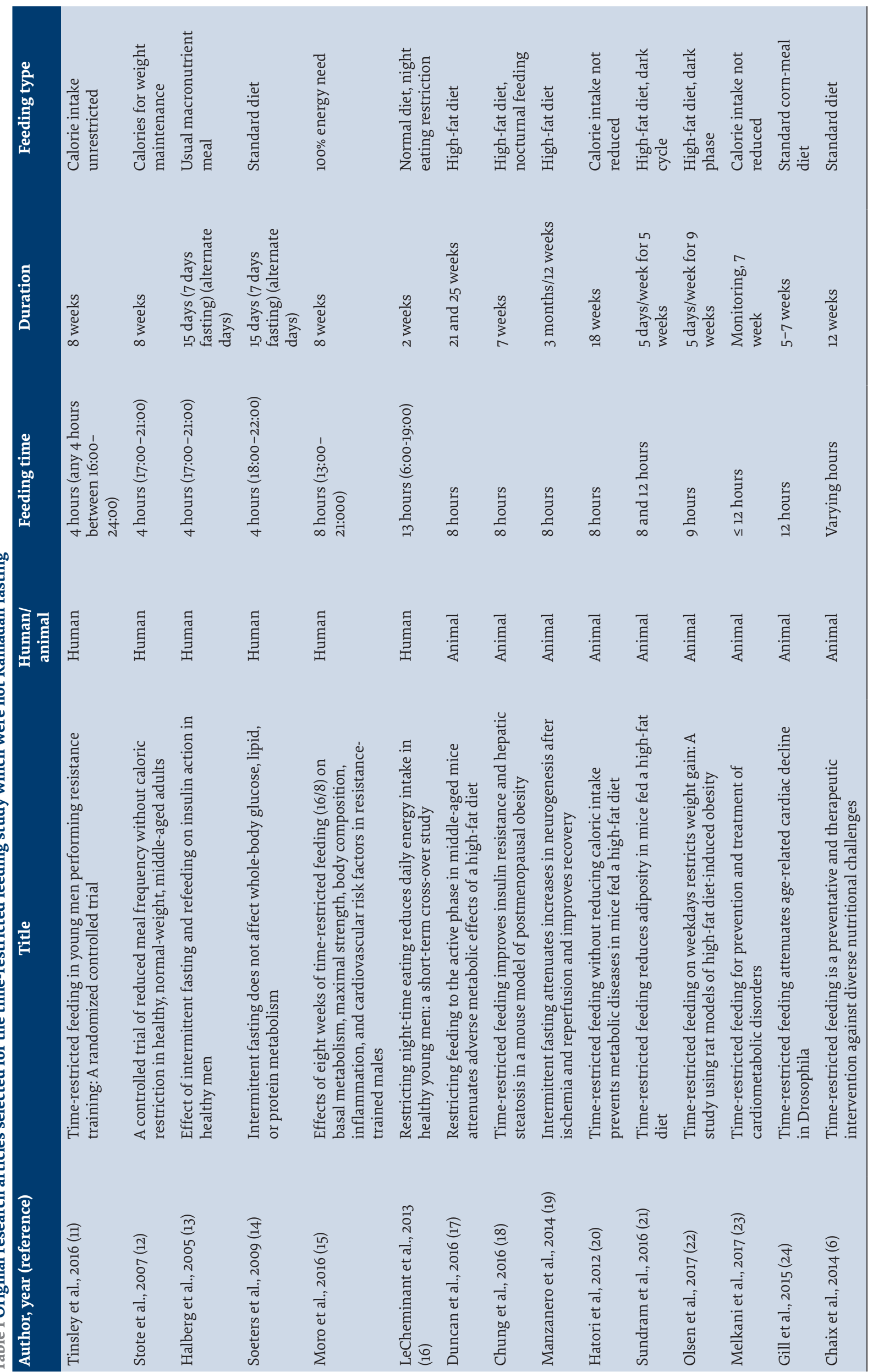




\section{Duration of fasting and meal frequency}

The duration of fasting in the time-restricted feeding research varied, ranging from 2 to 25 weeks. Among the research on human, the shortest duration was 2 weeks (16), while the longest was 8 weeks $(11,12,15)$. However, among the animal experiments, the longest duration was 25 weeks (16). In Islamic fasting, the longest duration of compulsory fasting is only a month (4 weeks) during Ramadan. Thus, the longest consecutive fasting time in Islamic fasting is less than in most of the time-restricted feeding research on human or animal's experiment that we reviewed.

The pattern of the duration of fasting in timerestricted feeding studies also varies. In general, the fasting is consecutive days but in two studies with humans, it was alternate days $(13,14)$. As for the pattern in voluntary Islamic fasting, there are many variations as this fasting is unrestricted and undertaken according to the wishes and ability of the person. It could be fasting for one or two specific days a week or three days a month or on alternate days.

As explained earlier, Islamic fasting, particularly in Ramadan, has both a circadian cycle of feeding (eating at night only) and a reduction in daily meal frequency (not more than twice or three times a day). In Ramadan fasting, Muslims do not usually eat all night and meal frequency is restricted to twice or three times between the period of sunset and sunrise: at the time of breaking fast (sunset), after the voluntary night prayers before sleeping and during pre-dawn meal. Reducing meal frequency to only once daily has been shown to significantly reduce fat mass without affecting most physiological variables such as heart rate, body temperature and blood metabolites (32). Thus, reducing meal frequency among Muslims who eat more than three meals outside of Ramadan could result in similar benefits (32).

\section{Calorie and water restriction}

As mentioned earlier, the definition of fasting varies. Among the more commonly known definition of fasting in the contemporary non-Islamic context, fasting is restricting consumption to only water or allowing a certain amount of low-calorie intake food. The time-restricted feeding studies with humans included in this review did not restrict calorie intake. The animal experiments also had no calorie restrictions; most used a high-fat diet or the same amount of calories (6,17-24). Similar to most time-restricted feeding studies, Islamic fasting has no calorie restrictions.

However, Islamic fasting does not allow water consumption. Therefore, the stress to the physiological system during Islamic fasting is different from that of the contemporary, non-Islamic fasting. During fasting, dehydration certainly occurs; however, studies have shown it to be safe for healthy individuals (33), and no adverse effects have been reported for people with chronic kidney disease and diabetes and pregnant women, even though they are not obliged to fast (28,34-37). However caution is advised for people with moderate to severe chronic kidney disease 28).

\section{Health benefits}

Although there are few studies on time-restricted feeding, especially on humans, research has shown health benefits and were highlighted in systematic reviews. Most research on time-restricted feeding has focused on body weight as one of the study variables. The main health benefits identified from time-restricted feeding research related to weight are: reduction in energy intake $(11,18)$, reduction in weight, and prevention of excessive body weight gain $(6,18,22,23)$. Other health benefits are: reduction in body fat (15), improvement in glucose tolerance and insulin resistance $(6,18)$, cardiometabolic benefits (24). Similarly, research on Islamic fasting has also focused on weight, in addition to the effects of fasting on blood lipid profile and glucose tolerance. Systematic reviews of Ramadan fasting showed weight reduction and improved blood lipid profiles $(29,30,38)$.

In general, research on time-restricted feeding and Islamic fasting shows weight reduction. Prevention of weight gain, or weight maintenance, has been studied in time-restricted feeding but this has not been well studied in Islamic fasting. However, a study promoting voluntary Islamic fasting after Ramadan showed postRamadan weight gain was controlled $(39,40)$. Examples of other variables studied in time-restricted feeding are body fat and blood cholesterol, which showed overall improvement, and these findings are similar to findings in Ramadan fasting. Thus, even without any restriction on calorie intake or type of food in Islamic fasting, there were some noteworthy health benefits.

\section{Conclusions and recommendations}

Ramadan fasting is a type of time-restricted feeding because the time period of feeding is restricted in Ramadan fasting, similar to the time-restricted feeding in the contemporary, non-Islamic fasting. In fact, in one of the systematic reviews of time-restricted feeding documented that among 11 human studies, nine were on Ramadan fasting (27).

There is some empirical evidence of the health benefit of time-restricted feeding and Islamic fasting (compulsory Ramadan fasting and voluntary fasting), including weight reduction. However, Islamic fasting does not involve much dietary intervention or restriction and does not incur any additional costs, whereas some dietary interventions have special diet bars or snacks, or low calorie formulas which could be expensive. Therefore, it is recommended that Islamic fasting is further studied at clinical and community levels to ascertain if it could be considered a strategy to improve health and weight management, especially in the global Muslim community.

Funding: None.

Competing interests: None declared. 


\section{Comparaison entre la prise alimentaire limitée dans le temps et le jeûne islamique : étude de portée}

\section{Résumé}

Contexte : La recherche sur les bienfaits du jeûne pour la santé se développe ; ceci inclut la prise alimentaire limitée dans le temps et le jeûne islamique.

Objectifs : Le présent article a pour objectif de passer en revue et de souligner les similitudes et les différences entre la prise alimentaire limitée dans le temps et le jeûne islamique pendant le Ramadan.

Méthodes: Une étude de portée a été entreprise pour identifier les articles pertinents qui répondaient à la question de recherche : quelles sont les similitudes et les différences dans les caractéristiques de la prise alimentaire limitée dans le temps et du jeûne islamique ? Des recherches ont été réalisées sur MEDLINE/PubMed en utilisant les termes : prise alimentaire limitée dans le temps et poids. Les critères d'inclusion étaient les suivants : articles de recherche originaux et analyses, rédigés en anglais et publiés entre 2000 et 2017.

Résultats et discussion : Au total, 25 articles correspondant à la question de recherche ont été inclus dans l'analyse : 15 articles de recherche originaux et 10 analyses. Les résultats laissent penser que le jeûne du Ramadan est une forme de prise alimentaire limitée dans le temps dans le contexte contemporain en raison de la période où l'alimentation n'est pas autorisée. La durée du jeûne signalée dans les cas d'alimentation à durée limitée variait de 4 à 24 heures, ce qui est plus long que dans le cas du jeûne islamique, qui dure entre 8 et 20 heures. On a constaté que la prise alimentaire limitée dans le temps et le jeûne islamique ont des effets positifs sur la santé, y compris la perte de poids.

Conclusion: L'alimentation limitée dans le temps et le jeûne islamique présentent de nombreuses caractéristiques similaires ainsi quet des effets positifs sur la santé constatés.

$$
\begin{aligned}
& \text { مقارنة التغذية المقيدة بالوقت والصيام الإسلامي: مراجعة استكشافية }
\end{aligned}
$$

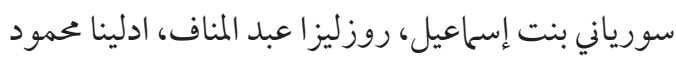

$$
\begin{aligned}
& \text { الخلاصة } \\
& \text { الخلفية: البحوث حول الفو ائد الصحية للصيام آخذة في الازدياد؛ وهذا يشمل التغذية المقيدة بالوقت والصيام الإسلامي. }
\end{aligned}
$$

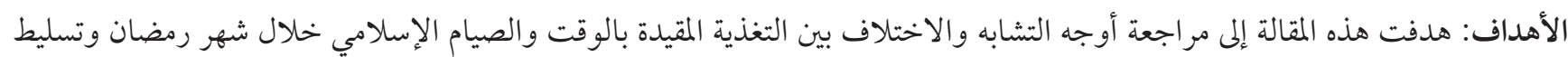

$$
\begin{aligned}
& \text { الضوء عليها. }
\end{aligned}
$$

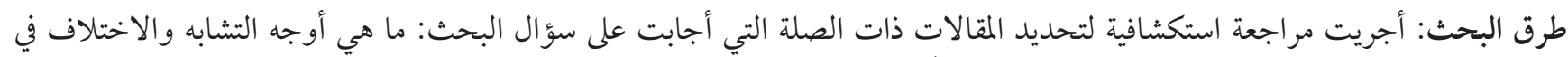

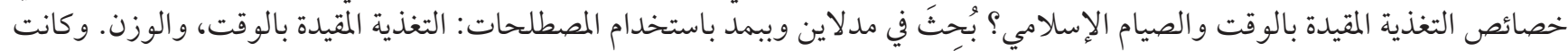

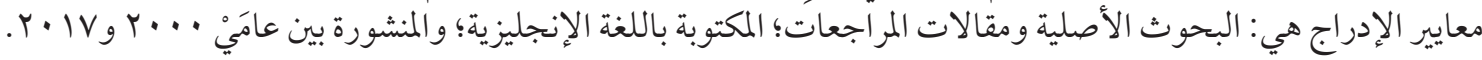

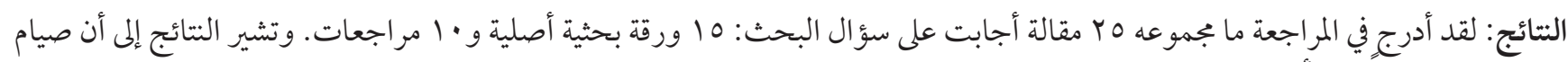

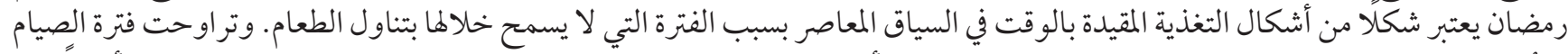

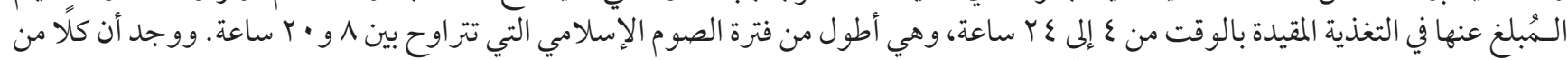

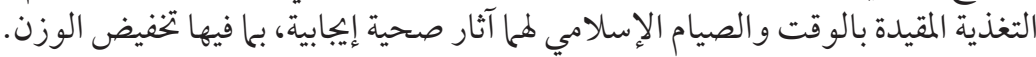

$$
\begin{aligned}
& \text { الاستتاجات: إن التغذية المقيدة بالوقت والصيام الإسلامي يتشابهان في العديد من الخصائص و التأثيرات الصحية الإيجابية التي أبلغ عنها. }
\end{aligned}
$$

\section{References}

1. Goldhamer A, Lisle D, Parpia B, Anderson SV, Campbell T. Medically supervised water-only fasting in the treatment of hypertension. J Manipulative Physiol Ther. 2001;24(5):335-9.

2. Safdie FM, Dorff T, Quinn D, Fontana L, Wei M, Lee C, et al. Fasting and cancer treatment in humans: A case series report. Aging. 2009;1(12):988-1007.

3. Johnstone A. Fasting for weight loss: an effective strategy or latest dieting trend? Int. J Obes. 2015;39(5):727-33.

4. Varady KA, Bhutani S, Klempel MC, Kroeger CM, Trepanowski JF, Haus JM, et al. Alternate day fasting for weight loss in normal weight and overweight subjects: a randomized controlled trial. J Nutr. 2013;12:146

5. Collier R. Intermittent fasting: the science of going without. CMAJ. 2013;185(9):E363-4.

6. Chaix A, Zarrinpar A, Miu P, Panda S. Time-restricted feeding is a preventative and therapeutic intervention against diverse nutritional challenges. Cell Metab. 2014;20(6):991-1005. 
7. Ahmad NB. Fasting in Countries Where the day is very long or very short: a study of muslims in the Netherlands. Al-Jami'ah. 2013;51(1):159-88.

8. Arksey H, O'Malley L. Scoping studies: towards a methodological framework. Int J Soc Res Methodol. 2005;8(1):19-32.

9. Levac D, Colquhoun H, O’Brien KK. Scoping studies: advancing the methodology. Implementation Sci. 2010;5:69.

10. Davis CS, Clarke RE, Coulter SN, Rounsefell KN, Walker RE, Rauch CE, et al. Intermittent energy restriction and weight loss: a systematic review. Eur J Clin Nutr. 2016;70(3):292-9.

11. Tinsley GM, Forsse JS, Butler NK, Paoli A, Bane AA, La Bounty, et al. Time-restricted feeding in young men performing resistance training: A randomized controlled trial. Eur J Sport Sci. 2016;17(2):200-7.

12. Stote KS, Baer DJ, Spears K, Paul DR, Harris GK, Rumpler WV, et al. A controlled trial of reduced meal frequency without caloric restriction in healthy, normal-weight, middle-aged adults. Am J Clin Nutr. 2007;85(4):981-8.

13. Halberg N, Henriksen M, So"derhamn N, Stallknecht B, Ploug T, Schjerling P, et al. Effect of intermittent fasting and refeeding on insulin action in healthy men. J Appl Physiol. 2005;99(6):2128-36.

14. Soeters MR, Lammers NM, Dubbelhuis PF, Ackermans, MT, Jonkers-Schuitema CF, Fliers, et al. Intermittent fasting does not affect whole-body glucose, lipid, or protein metabolism. Am J Clin Nutr. 2009;90(5):1244-51.

15. Moro T, Tinsley G, Bianco A, Marcolin G, Pacelli QF, Battaglia G, et al. Effects of eight weeks of time-restricted feeding (16/8) on basal metabolism, maximal strength, body composition, inflammation, and cardiovascular risk factors in resistance-trained males. J Transl Med. 2016;14(1):290.

16. LeCheminant JD, Christenson E, Bailey BW, Tucker LA. Restricting night-time eating reduces daily energy intake in healthy young men: a short-term cross-over study. Br J Nutr. 2013;110(11):2108-13.

17. Duncan MJ, Smith JT, Narbaiza J, Mueez F, Bustle LB, Qureshi S, et al. Restricting feeding to the active phase in middle-aged mice attenuates adverse metabolic effects of a high-fat diet. Physiol Behav. 2016; 67:1-9.

18. Chung H, Chou W, Sears DD, Patterson RE, Webster NJ, Ellies LG. Time-restricted feeding improves insulin resistance and hepatic steatosis in a mouse model of postmenopausal obesity. Metabolism. 2016;65(12):1743-54.

19. Manzanero S, Erion JR, Santro T, Steyn FJ, Chen C, Arumugam TV, et al. Intermittent fasting attenuates increases in neurogenesis after ischemia and reperfusion and improves recovery. J Cereb Blood Flow Metab. 2014;34(5):897-905.

20. Hatori M, Vollmers C, Zarrinpar A, DiTacchio L, Bushong EA, Gill S, et al. Time-restricted feeding without reducing caloric intake prevents metabolic diseases in mice fed a high-fat diet. Cell Metab. 2012;15(6):848-6.

21. Sundaram S, Yan L .Time-restricted feeding reduces adiposity in mice fed a high-fat diet. Nutr Res. 2016;36(6):603-11.

22. Olsen MK, Choi MH, Kulseng B, Zhao CM, Chen D. Time-restricted feeding on weekdays restricts weight gain: A study using rat models of high-fat diet-induced obesity. Physiol Behav. 2017;173:298-304.

23. Melkani GC, Panda S. Time-restricted feeding for prevention and treatment of cardiometabolic disorders. J Physiol. 2017;595(12):3691-700.

24. Gil S, Le HD, Melkani GC, Panda S. Time-restricted feeding attenuates age-related cardiac decline in Drosophila. Science. 2015; 347(6227):1265-9.

25. Kinsey AW, Ormsbee MJ. The health impact of nighttime eating: old and new perspectives. Nutrients. 2015;7(4):2648-62.

26. Sherman H, Genzer Y, Cohen R, Chapnik N, Madar Z, Froy O. Timed high-fat diet resets circadian metabolism and prevents obesity. FASEB J. 2012;26(8):3493-502.

27. Rothschild J, Hoddy KK, Jambazian P, Varady KA. Time-restricted feeding and risk of metabolic disease: a review of human and animal studies. Nutr Rev. 2014;72(5):308-18.

28. Bragazzi NL. Ramadan fasting and chronic kidney disease: A systematic review. J Res Med Sci. 2014;19(7):665-76.

29. Sadeghirad B, Motaghipisheh S, Kolahdooz F, Zahedi MJ, Haghdoost AA. Islamic fasting and weight loss: a systematic review and meta-analysis. Public Health Nutr. 2014;17(2):396-406.

30. Mazidi M, Rezaie P, Chaudhri O, Karimi E, Nematy M. The effect of Ramadan fasting on cardiometabolic risk factors and anthropometrics parameters: A systematic review. Pak J Med Sci. 2015;31(5):1250-5.

31. Gallant AR, Lundgren J, Drapeau V. The night-eating syndrome and obesity. Obes Rev. 2012;13(6):528-36.

32. Carlson O, Martin B, Mattson MP. Impact of reduced meal frequency without caloric restriction on glucose regulation in healthy, normal weight middle-aged men and women. Metabolism. 2007;56(12):1729-34.

33. Asegaonkara SB, Jayshree IK, Avinash, P, Sunita A, Anand PT. Effect of Ramadan fasting on renal function markers in healthy adults from Aurangaba. Walawalkar Int Med J. 2014;1(1):13-7.

34. Hendawy A. Effect of fasting on renal physiology. J Nutr Fasting Health. 2014;2(3):110-2.

35. Rouhani MH, Azadbakht L. Is Ramadan fasting related to health outcomes? A review on the related evidence. J Res Med Sci. 2014;19(10):987-92.

36. Leiper JB, Molla AM, Molla AM. Effects on health of fluid restriction during fasting in Ramadan. Eur J Clin Nutr. 2003;57(2): S30-8. 
37. Nematy M, Mazidi M, Rezaie P, Kazemi M, Norouzy A, Mohajeri SAR, et al. Ramadan fasting: Do we need more evidence? J Nutr Fasting Health. 2015;3(1):4-10.

38. Kul S, Savaş E, Öztürk ZA, Karadağ G. Does Ramadan fasting alter body weight and blood lipids and fasting blood glucose in a healthy population? A meta-analysis. J Relig Health. 2014;53(3):929-42.

39. Suriani I, Shamsuddin K, Khalib AL, Hazizi AS, Latifah AM, Fadlan MO. Voluntary fasting to control post-ramadan weight gain among overweight and obese women. Sultan Qaboos Univ Med J. 2015;15(1):e98-104.

40. Suriani I, Shamsuddin K, Khalib AL, Hazizi AS, Latifah AM, Fadlan MO. Comparing the sustainability of an Islamic dietary intervention to maintain weight loss 6 months after Ramadan between intervention and control groups. J Nutr Fasting Health. 2015;3(2):86-93. 